\title{
THE CRAYFISH PLAGUE INTHE CZECH REPUBLIC - REVIEW OF RECENT SUSPECT CASES AND A PILOT DETECTION STUDY
}

\author{
E. KOZUBíKOVÁ (1), A. PETRUSEK (1), Z. ĎURIŠ (2), P. KOZÁK (3), S. GEIGER (4), \\ R. HOFFMANN (4), B. OIDTMANN $(4,5)$
}

(1) Department of Ecology, Charles University, Viničná 7, Prague 2, CZ-12844, Czech Republic. E-Mail: evikkk@post.cz

(2) Department of Biology, University of Ostrava, Chittussiho 10, Ostrava, CZ-71000, Czech Republic.

(3) University of South Bohemia in České Budějovice, Research Institute of Fish Culture and Hydrobiology, Zátiší 728/II, Vodňany, CZ-38925, Czech Republic.

(4) Institute for Zoology, Fish Biology \& Fish Diseases, Ludwig-Maximilians-Universität, Kaulbachstr. 37, D-80539, Munich, Germany.

(5) CEFAS Weymouth Laboratory, Barrack Road, The Nothe, Weymouth, Dorset DT4 8UB, United Kingdom

Reçu le 29 septembre 2005

Accepté le 9 mars 2006

Received September 29, 2005

Accepted March 9, 2006

\begin{abstract}
There are only very limited reports about the occurrence of the crayfish plague in Czechia. In recent years, mass mortalities of Astacus spp. with symptoms of possible crayfish plague were noticed in three streams in the country - two in Central Bohemia (1998-9) and one in Silesia (2004). Three dead individuals from the last outbreak were examined for the presence of the crayfish plague pathogen, Aphanomyces astaci, by observation of the presence of hyphae in their cuticle and by a PCR-based diagnostic method. In all three cases the detection was positive. Although causes of mass mortalities from two other localities lack such a direct confirmation, the indirect evidence supports the same conclusion. The main potential vector of $A$. astaci in Czechia is the American spiny-cheeck crayfish Orconectes limosus, widespread in large rivers of the western part of the country and in various isolated standing waters. Using the same molecular method, we investigated the presence of $A$. astaci in living $O$. limosus individuals from six localities (three running and three standing waters). The analysis indicated the presence of the pathogen in animals from five out of six investigated Orconectes populations. One of them is present in the stream where two European Astacus species had gone extinct in 1998-9. Our results suggest that the crayfish plague is still present in Czechia, and that populations of $O$. limosus represent a reservoir for the crayfish plague pathogen, which directly endangers populations of the native crayfish.
\end{abstract}

Key-words: crayfish plague, Aphanomyces astaci, oomycete, mass mortality, Czech Republic, molecular diagnosis, PCR, Orconectes limosus, Astacus astacus. 


\section{LA PESTE DES ÉCREVISSES EN RÉPUBLIQUETCHÈQUE - EXAMEN DES CAS SUSPECTS RÉCENTS ET UNE ÉTUDE PILOTE DE DÉTECTION}

\section{RÉSUMÉ}

II n'y a que peu de comptes rendus sur la présence de la peste des écrevisses en République Tchèque. Ces dernières années, la mortalité d'Astacus spp. avec des symptômes de la peste des écrevisses ont été relevés dans trois cours d'eau en République tchèque - deux en Bohème centrale (1998-9) et une en Silésie (2004). On a examiné la présence d'Aphanomcyes astaci, un parasite oomycète causant cette peste, dans trois individus morts lors de la dernière épidémie, utilisant des observations directes du mycélium de l'agent pathogène dans la cuticule, ainsi qu'une méthode de diagnostic à base de PCR. À chaque occasion, les résultats furent positifs. Bien que les causes de mortalité dans deux autres localités manquent de confirmations directes, des évidences indirectes supportent la même conclusion. La peste des écrevisses est traditionnellement transmise par Orconectes limosus, une écrevisse nord américaine. Cette espèce est largement répandue dans les grands fleuves à l'ouest du pays et dans les eaux stagnantes. Par la même méthode moléculaire, nous avons étudié la présence d'A. astaci chez des individus vivants d'O. limosus de six localités (trois en eaux courantes et trois en eaux stagnantes). La présence de l'agent pathogène était confirmée chez les animaux dans cinq de ces populations d'O. limosus, dont une présente dans un cours d'eau où deux espèces d'Astacus s'était éteintes en 1998-9. Nos résultats indiquent que la peste reste présente en République tchèque, et les populations d'O. limosus sont un réservoir pour son agent pathogène qui menace directement les populations d'écrevisses natives.

Mots-clés : peste des écrevisses, Aphanomyces astaci, oomycète, mortalité de masse, République tchèque, diagnostic moléculaire, PCR, Orconectes limosus, Astacus astacus.

\section{INTRODUCTION}

Crayfish plague is the best-known and probably the most serious disease of freshwater crayfish (CERENIUS et al., 1988; EDGERTON et al., 2004), caused by the parasitic oomycete Aphanomyces astaci of North American origin. For European and Australasian species of crayfish, the infection by the plague pathogen is fatal (ALDERMAN et al., 1987). However, crayfish species native to North America are much more resistant to the acute disease (UNESTAM, 1969; PERSSON and SÖDERHÄLL, 1983; DIÉGUEZURIBEONDO and SÖDERHÄLL, 1993). They act as carriers of $A$. astaci, and thus represent one of the most significant threats for other crayfish species (CERENIUS et al., 1988).

Two crayfish species are native to the Czech Republic, the noble crayfish Astacus astacus and the stone crayfish Austropotamobius torrentium (KOZÁK et al., 2002). Another indigenous European species, the narrow-clawed crayfish Astacus leptodactylus, was introduced to the country from Eastern Europe at the end of the $19^{\text {th }}$ century (ŠTĚPÁN, 1932-33; ĎURIŠ and HORKÁ, 2001). It became naturalised and is now considered as an integral part of the Czech fauna. Additionally, two non-indigenous species of crayfish of North American origin are present in Czechia: the spiny-cheek crayfish Orconectes limosus and the signal crayfish Pacifastacus leniusculus (HOLDICH, 2003). P. leniusculus was introduced in 1980 and is still known only from a few localities, whereas O. limosus had spread to the country already in the 1960s and is now common, especially in large rivers of the Elbe watershed and in a number of isolated standing waters (PETRUSEK et al., 2006). Both of these American crayfish are known carriers of crayfish plague (VEY et al., 1983; ALDERMAN et al., 1990). 
Knowledge of the prevalence of the crayfish plague pathogen is necessary for efficient protection of indigenous crayfish species and management of potential reintroduction attempts. Unfortunately, a reliable diagnosis of $A$. astaci is generally tedious and difficult, requiring cultivation of the pathogen with subsequent infection experiments on susceptible crayfish (CERENIUS et al., 1988; OIDTMANN et al., 1999). Recently, however, molecular tools were developed in order to speed up the identification of $A$. astaci from cultures and clinical samples (OIDTMANN et al., 2002, 2004), and also to test for the presence of the pathogen in crayfish carriers (OIDTMANN et al., 2005). In the present study, we used the PCR-based detection method to investigate the cause of a mass mortality of a native crayfish species, and to test for the presence of latent infection in American crayfish from Czech localities. Due to the lack of proper diagnostic methods, the pathogen could not be reliably confirmed in Czechia before, therefore our study presents the first actual evidence of the contemporary occurrence of $A$. astaci in the territory of the Czech Republic. We also review several cases of mass mortalities in the $20^{\text {th }}$ century, probably caused by the crayfish plague.

\section{MATERIAL AND METHODS}

For the molecular detection of the presence of $A$. astaci, we collected dead A. astacus from a mass mortality with suspicion of a crayfish plague outbreak in the Krivec brook in the town Trinec (49 $\left.40^{\prime} \mathrm{N}, 1^{\circ} 40^{\prime} \mathrm{E}\right)$ on September 15, 2004, and living O. limosus from six populations in the Czech Republic, including both running and standing waters (Table I). The position of all localities is shown in Figure 1.

\section{Table I}

Origin of Orconectes limosus populations tested for the presence of Aphanomyces astaci.

Tableau I

Origine des populations d'Orconectes limosus testées pour la présence d'Aphanomyces astaci.

\begin{tabular}{|l|l|l|l|l|l|}
\hline \multicolumn{1}{|c|}{ Locality } & $\begin{array}{c}\text { Locality } \\
\text { character }\end{array}$ & $\begin{array}{c}\text { Closest } \\
\text { settlement }\end{array}$ & Latitude & Longitude & $\begin{array}{c}\text { Date of } \\
\text { sampling }\end{array}$ \\
\hline Stará pískovna & sandpit & Provodín & $50^{\circ} 37^{\prime} \mathrm{N}$ & $14^{\circ} 36^{\prime} \mathrm{E}$ & 13.9 .2004 \\
\hline Pšovka & stream & Lhotka & $50^{\circ} 23^{\prime} \mathrm{N}$ & $14^{\circ} 33^{\prime} \mathrm{E}$ & 13.9 .2004 \\
\hline Elbe & river & Mělník & $50^{\circ} 21^{\prime} \mathrm{N}$ & $14^{\circ} 28^{\prime} \mathrm{E}$ & 13.9 .2004 \\
\hline Kojetice - quarry & quarry & Kojetice & $50^{\circ} 14^{\prime} \mathrm{N}$ & $14^{\circ} 31^{\prime} \mathrm{E}$ & 15.9 .2004 \\
\hline Jickovický potok & stream & Jickovice & $49^{\circ} 26^{\prime} \mathrm{N}$ & $14^{\circ} 13^{\prime} \mathrm{E}$ & 15.9 .2004 \\
\hline Orlík reservoir & reservoir & Strouhy & $49^{\circ} 20^{\prime} \mathrm{N}$ & $14^{\circ} 17^{\prime} \mathrm{E}$ & 9.7 .2003 \\
\hline
\end{tabular}

Living O. limosus were hand collected and transported to the laboratory in boxes, containing wet grass as a substrate. Animals from the reservoir Orlík were preserved in $70 \%$ ethanol. Animals from other localities were kept alive before analysis (up to two weeks for some populations), those from the same population sharing a common aquarium. Aquaria were aerated, with unidirectional water flow allowing frequent exchange of the aquarium volume, and contained sufficient amount of shelters for the animals. The number of individuals from each locality was variable, depending on the availability of material. All available specimens were tested for the presence of $A$. astaci in the abdominal cuticle. 
Freshly dead $A$. astacus from the Krivec brook were kept on ice after the collection. Three randomly selected individuals were used for the diagnosis. Before the DNA extraction, the soft abdominal cuticle of the dead crayfish was inspected microscopically for the presence of hyphae.

Living O. limosus were killed using chloroform vapours. The details of cuticle dissection and extraction protocol are given in OIDTMANN et al. (2004). Dissection tools and the workspace were disinfected after processing each individual. The total genomic DNA from the crayfish cuticle was extracted by the QIAamp DNA Mini Kit (Qiagen) according to the manufacturer's instructions.

The protocol used for detection of $A$. astaci genetic material (OIDTMANN et al., 2005) is a further improvement of the method presented by OIDTMANN et al. (2004). The protocol applied here introduces another outer PCR round before using the primers presented in OIDTMANN et al. (2004). This approach increases the specificity of the assay due to the use of an additional species-specific primer. The detection is considered positive if the second PCR step yields a product of identical length as that from the positive control (DNA isolate from a pure $A$. astaci culture). The details of the protocol are described in a separate publication (OIDTMANN et al., submitted).

\section{RESULTS}

\section{Crayfish mass mortalities in Czechia: case studies}

The area of Czechia was hit by crayfish plague during the first wave of the plague spread on European continent, at the end of the $19^{\text {th }}$ century. Between the years 1883 and 1906 many crayfish populations, which had been dense and continuous until that time, were decimated (KRUPAUER, 1968; LOHNISKÝ, 1983). The infection had spread to the country probably from two directions (Figure 1), from southeastern Germany (Bavaria) to Bohemia (western part of the Czech Republic) and from southern Poland (Silesia) to Moravia (eastern part of the country) (KRUPAUER, 1968).

Later during the $20^{\text {th }}$ century, only a few records of isolated mass mortalities of crayfish have been reported in Czechia with sufficient details to allow speculations about crayfish plague as the cause of mortality. There have very likely been more isolated plague outbreaks in the territory but these mostly stayed either undetected or unreported, or the disease was not identified as the cause. VOTRUBEC (1931) stated that isolated crayfish plague outbreaks occurred infrequently in the country; however, he did not list any particular localities. The locations of the mortalities described below are shown in Figure 1.

In 1924, crayfish (most likely A. astacus) were wiped out in the river Jemčina near the town Jindřichův Hradec and in the watershed of the river Volyňka near the town Volyně, both in southern Bohemia (VOLF, 1926). The case of the Volyňka was described in more details. Large numbers of dead crayfish were observed and the infection quickly spread upstream. The mortality was restricted to crayfish only. These symptoms rule out pollution as the cause of the mortality and point to a probable outbreak of crayfish plague.

To our knowledge, the next likely crayfish plague outbreaks were not reported until the late 1990s (apart from the general note of VOTRUBEC in 1931). In 1998-1999, a mass mortality of $A$. astacus and $A$. leptodactylus occurred in the Pšovka brook, a tributary of the Elbe, in central Bohemia (north of Prague). This case is interesting because of the presence of three crayfish species in a single watercourse. BERAN (1995) described the situation in the locality in 1994: A. astacus was present in the upper and middle part of the brook, and in ponds connected with the watercourse where it coexisted with 


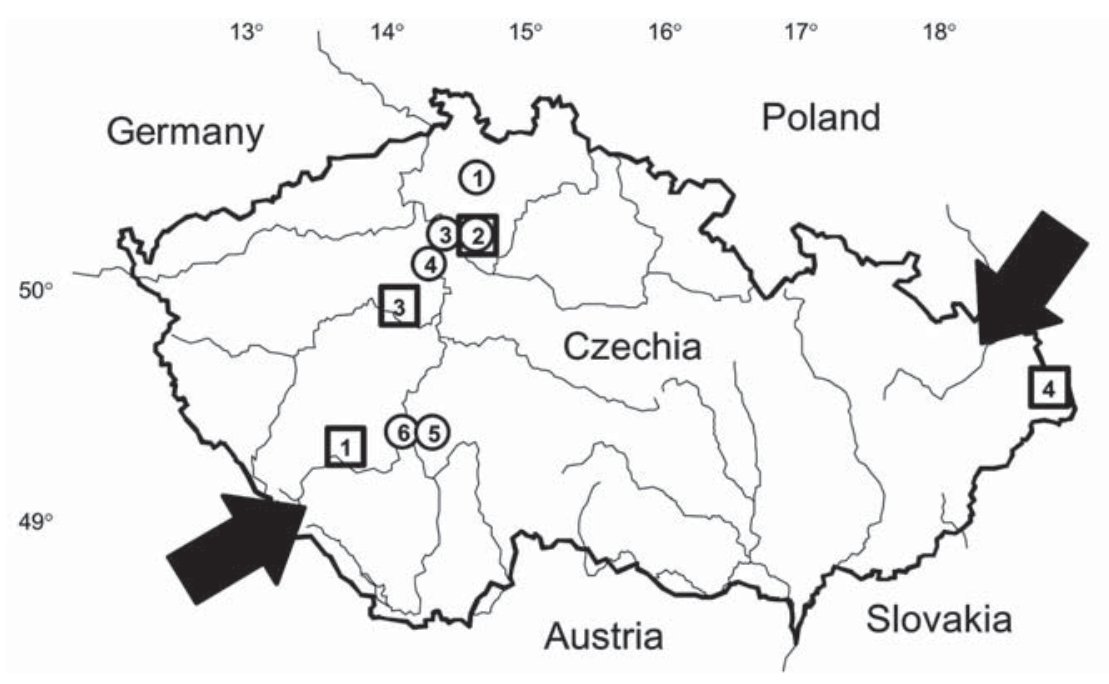

Figure 1

Location of the presumed crayfish plague outbreaks in Czechia, discussed in the text (squares), populations of Orconectes limosus sampled for the study (circles), and directions of the crayfish plague spread into the country at the end of $19^{\text {th }}$ century (arrows).

\section{Figure 1}

Localisation des apparitions présumées de la peste des écrevisses en République tchèque, discutées dans le texte (carrés), populations d'Orconectes limosus échantillonnées pour l'étude (cercles), et dissémination directe de la peste des écrevisses dans le pays à la fin du XIX ${ }^{\mathrm{e}}$ siècle (flèches).

Mass mortalities (squares):

Mortalités de masse (carrés) :

1 - river Volyňka, 1924; 2 - brook Pšovka, 1998-9; 3 - brook Loděnice, 1999; 4 - brook Křivec, 2004.

\section{Sampled localities (circles):}

Localités échantillonnées (cercles) :

1 - sandpit Stará pískovna, 2 - brook Pšovka, 3 - river Elbe (Labe), 4 - quarry Kojetice,

5 - brook Jickovický potok, 6 - reservoir Orlík.

A. leptodactylus. In the lower part of the brook O. limosus was observed, in one place cooccurring with infrequent individuals of $A$. leptodactylus. According to a local fisherman, the spiny-cheek crayfish were intentionally stocked by humans to a pond on the brook, following an undocumented mass mortality of the noble crayfish at the end of the 1980s. A new mass mortality of Astacus species in the Pšovka started in May 1998 and spread upstream during the summer and the following year. Thousands of moribund or dead crayfish, mostly $A$. astacus, could be found in the stream. The infection did not affect Orconectes individuals or other organisms, and the chemical analysis of the stream water did not show any abnormal contamination (KOZÁK et al., 2000a).

In 1999, a mass mortality of $A$. astacus spreading upstream was observed in the Loděnice brook in central Bohemia (west of Prague). Similarly to the previous case, the chemical analysis did not show any changes of water quality and no other organisms were affected, which again points to a possible crayfish plague outbreak (KOZÁK et al., 2000b). 
The most recent analysed plague outbreak in the Czech Republic was recorded in the brook Krrivec in Trinec (Silesia, north-east part of the country). Mass mortality of $A$. astacus was observed in this watercourse in September 2004. No other crayfish species were present at the locality. On the collection date, most noble crayfish were dead or dying out of the shelters, often with missing claws or legs. In the lower part of the affected region of the stream, all crayfish were dead in various stages of decomposition; recently dead as well as dying crayfish were found in the upper part. However, some crayfish were alive at the time of the sampling, with no visible symptoms of a disease. Fish and other aquatic macroinvertebrates in the stream were not affected, excluding poisoning or oxygen depletion as the cause of the crayfish mass mortality.

\section{Detection of Aphanomyces astaci in Czech crayfish}

Microscopic examination of the soft abdominal cuticle of dead $A$. astacus from the mass mortality in the Krivec brook revealed presence of a dense growth of branching, aseptated hyphae with round tips growing within the cuticle, typical of $A$. astaci. This observation was in agreement with the PCR-based detection - all three individuals tested positive (Figure 2A).
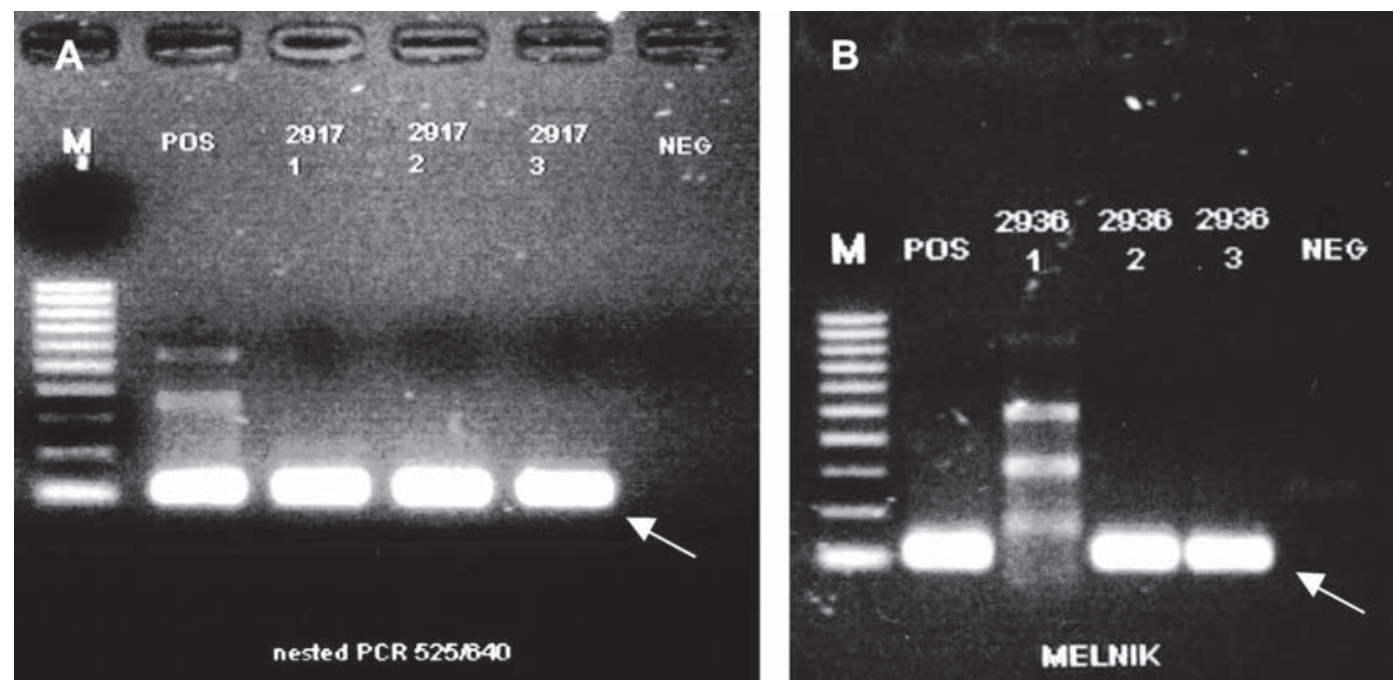

Figure 2

Example of agarose gels with results of the molecular detection of Aphanomyces astaci. A: analysis of three dead noble crayfish from the $\mathbf{2 0 0 4}$ mass mortality in the Křivec brook, B: analysis of three living spiny-cheek crayfish from the river Elbe near Mělník. Bright band at 115 bp (arrow) indicates positive detection. M - 100 bp size marker; POS - positive control (DNA isolated from the $A$. astaci culture); NEG - negative control; 1,2,3 - DNA isolates from the crayfish cuticle.

\section{Figure 2}

Gels d'agarose montrant la présence d'Aphanomyces astaci à base de méthodes moléculaires. A: analyse de trois spécimens d'Astacus morts, ramassés lors de la mortalité massive dans le ruisseau Křivec. B : analyse de trois spécimens d'O. limosus provenant de l'Elbe près de Mělník. Les résultats positifs sont repérés par une bande claire de $115 \mathrm{pb}$ (flèche). $M$ : marqueur de tailles de fragments de $100 \mathrm{pb}$; POS : contrôle positif (ADN provenant de culture d'A. astaci) ; NEG : contrôle négatif ; 1, 2, 3 - isolats de cuticule d'écrevisse. 
A summary of the results of detection of $A$. astaci in O. limosus is shown in Table II. Latent infection was detected in the spiny-cheek crayfish from five out of six populations (example of one population is shown in Figure 2B). In three populations, over $50 \%$ of animals tested positive. In one locality (the brook Jickovický potok, a right-side tributary of the river VItava in the reservoir Orlík), all tested specimens were positive. The only locality of $O$. limosus where the presence of $A$. astaci was not detected in the analysed samples was the flooded sandpit Stará pískovna, which is isolated from other populations of crayfish.

\section{Table II}

Results of the molecular detection of Aphanomyces astaci in Orconectes limosus.

Tableau II

Résultats de la détection moléculaire d'Aphanomyces astaci chez Orconectes limosus.

\begin{tabular}{|l|c|c|c|}
\hline \multicolumn{1}{|c|}{ Locality } & Animals tested & Positive for $\boldsymbol{A}$. astaci & $\begin{array}{c}\text { Percentage of } \\
\text { infected animals }\end{array}$ \\
\hline Stará pískovna & 9 & 0 & $0 \%$ \\
\hline Pšovka & 10 & 6 & $60 \%$ \\
\hline Elbe & 3 & 2 & $67 \%$ \\
\hline Kojetice - quarry & 16 & 2 & $13 \%$ \\
\hline Jickovický brook & 15 & 15 & $100 \%$ \\
\hline Orlík reservoir & 20 & 5 & $25 \%$ \\
\hline
\end{tabular}

\section{DISCUSSION}

The diagnosis of $A$. astaci in the dead $A$. astacus from the Krivec brook (molecular evidence corroborated by the microscopic examination) is the first confirmation of this pathogen causing mass mortalities of native crayfish species in Czechia. The source of the infection of this plague outbreak is not known. There are no vectors of $A$. astaci present in the same locality or in its vicinity. The nearest population of $O$. limosus was present at least up to 1992 in the Goczałkowice reservoir, southern Poland (KRZYŹANEK and KASZA, 1998). This locality, however, belongs to a different watershed than the Krivec brook, and the current status of Orconectes presence there is unclear. As the outbreak was located in the outskirts of the town Trinec, an anthropogenic source of infection is the most likely explanation. It is possible that $A$. astaci was spread to this locality by fishermen. Another possible way of spread of the infection could be American crayfish released by aquarists.

The source of infection in the brook Loděnice where the crayfish population died out in 1999 is also unknown. In this case, however, a potential vector may have been at least present in the same watershed, in the river Berounka. The place where the crayfish mass mortality was first recorded was over $20 \mathrm{~km}$ upstream from the confluence of the Loděnice and the Berounka (but only about $9 \mathrm{~km}$ from the nearest stretch of the latter). $O$. limosus had been reported from the Berounka in 1992 (HAJER, 1994) but was not confirmed there at the time of the crayfish mortality (KOZÁK et al., 2000b) or later (PETRUSEK et al., 2006). 
Positive results of the molecular detection of $A$. astaci for individuals of $O$. limosus from the Pšovka brook (indicating a latent infection by the pathogen in the local spiny-cheek crayfish population) suggest that this species may have been the source of infection causing mass mortalities of the noble and narrow-clawed crayfish in this brook in 1998-1999.

We should, however, consider potential limitations of the molecular technique used. There remains a small likelihood that a sensitive PCR-based method may give false positive results. (Apart from contamination, a positive reaction to previously untested species or strains of non-pathogenic Aphanomyces cannot be completely excluded.) Whenever possible, especially in case of mass mortalities, it would therefore be beneficial to assess various lines of evidence, and corroborate results of one method with another (e.g. molecular detection together with microscopic examination of the animals affected by the disease, or with cultivation techniques).

The lack of records of crayfish plague outbreaks in Czechia during the $20^{\text {th }}$ century is probably due to various reasons. It is unlikely that many crayfish plague outbreaks occurred in the mid-20 ${ }^{\text {th }}$ century, since native crayfish populations had declined and North American crayfish, which could have served as carriers of the pathogen, were not present in the country until the 1960s (PETRUSEK et al., 2006). Although latent infection by the plague pathogen within native crayfish populations could have been present, the substrate for the plague pathogen was in general rare, and its spreading ability limited. Some later plague outbreaks may have not been identified, as declines in crayfish populations had been usually attributed to industrial, agricultural, and sewage pollution. Since the 1990s, however, the water quality of surface waters has improved and this, combined with restocking programs, is likely to have led to increased numbers of native crayfish populations. At the same time, non-native crayfish (especially O. limosus) have spread, often directly due to human-mediated translocations. Since more crayfish are present in Czech rivers and standing waters nowadays, they come into contact more often and the frequency of transmissions of the pathogen may increase.

Positive results of the molecular detection of $A$. astaci in most studied populations of the spiny-cheek crayfish suggest that the causal agent of the crayfish plague may be widespread in the country. Although in case of the disease carriers the molecular method cannot be easily confirmed with other approaches (microscopic examination is not sufficient; presence or absence of melanized spots is not always linked to the presence or absence of the latent infection; and the cultivation from carriers has a very low yield), already the indication that the pathogen may be present in a number of populations of the spiny-cheek crayfish in Czechia is alarming.

The locality Stará pískovna, where none of nine tested spiny-cheek crayfish specimens showed positive results, is a flooded sandpit with no tributaries or outflows, supplied by seepage water. Crayfish colonising such standing waters are very likely introduced by humans (PETRUSEK et al., 2006). It may be speculated that the population of $O$. limosus in Stará pískovna developed from a small number of non-infected animals. However, the number of animals tested is too low to draw conclusions on the carrier status within the entire population. Some reports document the coexistence of European and American crayfish species in a single locality (NYLUND and WESTMAN, 2000) or close vicinity (PÖCKL and PEKNY, 2002), which might be explained by the absence of $A$. astaci in the North American crayfish in those particular places.

\section{CONCLUSIONS}

This study shows that some of the recent mass mortalities of European crayfish species in Czechia were likely caused by the crayfish plague. In the last documented case, the presence of the plague pathogen was confirmed by two independent methods - a microscopic examination and molecular diagnosis. Our results also suggest that 
Aphanomyces astaci seems to be widespread within populations of the non-indigenous spiny-cheek crayfish Orconectes limosus. This confirms that the spread of North American crayfish within the country represents a significant threat to native crayfish populations. The same situation is present in other European countries (e.g. Germany, Great Britain, Finland, Spain, and Sweden), where crayfish plague outbreaks are presently not rare, and are related to the spread of non-native crayfish (mostly the signal crayfish Pacifastacus leniusculus) (HOLDICH, 2003; BOHMAN et al., 2006; DIÉGUEZ-URIBEONDO, 2006).

More detailed investigation of the presence of $A$. astaci in its carriers in Czechia, including $P$. leniusculus, monitoring of crayfish plague outbreaks and of non-indigenous crayfish spread in the country, and education of the wider public to prevent the translocation of plague carriers, are necessary for suitable protection management of endangered native crayfish.

\section{ACKNOWLEDGEMENTS}

Our research of invasive crayfish ecology and the crayfish plague was funded by the Grant Agency of the Charles University (project GAUK 141/2005 B Bio), the Czech Ministry of Education (MSM0021620828 and MSM6007665809) and the Czech Science Foundation (GAČR 206/03/0532). We thank the "Hlávka" Foundation for financial support for attending the Craynet final meeting, Monika Štambergová for providing some of the samples, Thomas KUNZ for support during the stay of EK in Munich, and David Hardekopf and Joachim Mergeay for language corrections. Javier Diéguez-Uribeondo and one anonymous referee provided a number of valuable comments, which helped to improve the previous version of the manuscript.

\section{REFERENCES}

ALDERMAN D.J., HOLDICH D., REEVE I., 1990. Signal crayfish as vectors in crayfish plague in Britain. Aquaculture, 86(1), 3-6.

ALDERMAN D.J., POLGLASE J.L., FRAYLING M., 1987. Aphanomyces astaci pathogenicity under laboratory and field conditions. Journal of Fish Diseases, 10(5), 385-393.

BERAN L., 1995. Raci v CHKO Kokořínsko, část 1. [Crayfish in the Landscape Protected Area Kokořínsko, part 1.] Ochrana prírody, 50, 114-115 (in Czech).

BOHMAN P., NORDWALL F., EDSMAN L., 2006. The effect of large-scale introduction of signal crayfish on the spread of crayfish plague in Sweden. Bull. Fr. Pêche Piscic., 380-381, 1291-1302.

CERENIUS L., SÖDERHÄLL K., PERSSON M., AXAJON R., 1988. The crayfish plague fungus Aphanomyces astaci diagnosis, isolation, and pathobiology. Freshwater Crayfish, 7, 131-144.

DIÉGUEZ-URIBEONDO J., 2006. The dispersion of the Aphanomyces astaci-carrier, Pacifastacus leniusculus by humans represents the main cause of disappearance of the indigenous crayfish Austropotamobius pallipes in Navarra. Bull. Fr. Pêche Piscic., 380-381,1303-1312.

DIÉGUEZ-URIBEONDO J., SÖDERHÄLL K., 1993. Procambarus clarkii Girard as a vector for the crayfish plague fungus, Aphanomyces astaci Schikora. Aquaculture and Fisheries Management, 24, 761-765.

ĎURIŠ Z., HORKÁ I., 2001. K výskytu raka bahenního Pontastacus (=Astacus) leptodactylus Eschscholtz na Karvinsku. [Occurrence of narrow-clawed crayfish Pontastacus (=Astacus) leptodactylus Eschscholtz in vicinity of Karviná.] Časopis Slezského zemského muzea z Opavě (A), 50 (supl.), 78-84. (Czech). 
EDGERTON B.F., HENTTONEN P., JUSSILA J., MANNONEN A., PAASONEN P., TAUGBØL T., EDSMAN L., SOUTY-GROSSET C., 2004. Understanding the causes of disease in European freshwater crayfish. Conservation Biology, 18(6), 1466-1474.

HAJER J., 1994. Expanze raků druhu Cambarus affinis Say ve vodách České republiky. [Expansion of the crayfish Cambarus affinis Say in surface waters of the Czech Republic.] Fauna Bohemiae Septentrionalis, 19, 123-128. (in Czech).

HOLDICH D.M., 2003. Crayfish in Europe - an overview of taxonomy, legislation, distribution, and crayfish plague outbreaks. In: Management \& Conservation of Crayfish, Proceedings of a conference held on 7th November 2002 at the Nottingham Forest Football Club, Nottingham, UK. HOLDICH D.M., SIBLEY P.J. (Eds), 15-34. Environment Agency, Bristol, UK.

KOZÁK P., ADÁMEK Z., ŘEHULKA J., 2000a. Úhyn raků v potoce Pšovka v roce 1998. [Mortality of crayfish in the brook Pšovka in 1998]. Study no. 17. In: Ekotoxikologie, praktická cvičení, část 2. Diagnostika havarijních úhynů ryb a dalších vodních organizmů. [Ecotoxicology, practical course, Part 2. Diagnosis of mass mortalities of fish and other aquatic organisms.] SVOBODOVÁ Z., MÁCHOVÁ J. (Eds), 109-112. Veterinární a farmaceutická univerzita Brno, Fakulta veterinární hygieny a ekologie, Brno, Czech Republic (in Czech).

KOZÁK P., ČERVINKA S., VLADÍK P., 2000b. Úhyn raků na potoce Loděnický (Kačák) v roce 1999. [Mortality of crayfish in the brook Loděnický (Kačák) in 1999]. Study no. 18. In: Ekotoxikologie, praktická cvičení, část 2. Diagnostika havarijních úhynů ryb a dalších vodních organizmů. [Ecotoxicology, practical course, Part 2. Diagnosis of mass mortalities of fish and other aquatic organisms.] SVOBODOVÁ Z., MÁCHOVÁ J. (Eds), 113-116. Veterinární a farmaceutická univerzita Brno, Fakulta veterinární hygieny a ekologie, Brno, Czech Republic (in Czech).

KOZÁK P., ĎURIŠ Z., POLICAR T., 2002. The stone crayfish Austropotamobius torrentium (Schrank) in the Czech Republic. Bull. Fr. Pêche Piscic., 367, 707-713.

KRUPAUER V., 1968. Zlatý rak. [The golden crayfish.] Nakladatelství České Budějovice, Czechoslovakia. 109 p. (in Czech).

KRZYŹANEK E., KASZA H., 1998. Raki zbiornika Goczałkowickiego [Crayfish of the Goczałkowice reservoir]. Przyroda Górnego Śląska, 13, 13 (in Polish).

LOHNISKÝ K., 1983. Raci v našich vodách. [Crayfish in our waters.] Rybářství, 6, 128-129 (in Czech).

NYLUNDV., WESTMAN K., 2000. The prevalence of crayfish plague (Aphanomyces astaci) in two signal crayfish (Pacifastacus leniusculus) populations in Finland. Journal of Crustacean Biology, 20, 777-785.

OIDTMANN B., BAUSEWEIN S., HÖLZLE L., HOFFMANN R., WITTENBRINK M., 2002. Identification of the crayfish plague fungus Aphanomyces astaci by polymerase chain reaction and restriction enzyme analysis. Veterinary Microbiology, 85(2), 183194.

OIDTMANN B., CERENIUS L., SCHMID I., HOFFMANN R., SÖDERHÄLL K., 1999. Crayfish plague epizootics in Germany - classification of two German isolates of the crayfish plague fungus Aphanomyces astaci by random amplification of polymorphic DNA. Diseases of Aquatic Organisms, 35(3), 235-238.

OIDTMANN B., CULAS A., GEIGER S., HOFFMANN R.W., 2005. A molecular method for the detection of Aphanomyces astaci in American crayfish (detection crayfish plague carriers). 12th International Conference "Diseases of Fish and Shellfish", 1116 September 2005, Copenhagen, Denmark; book of abstracts O-135. 
OIDTMANN B., SCHAEFERS N., CERENIUS L., SÖDERHÄLL K., HOFFMANN R. W., 2004. Detection of genomic DNA of the crayfish plague fungus Aphanomyces astaci (Oomycete) in clinical samples by PCR. Veterinary Microbiology, 100(3-4), 269-282.

PERSSON M., SÖDERHÄLL K., 1983. Pacifastacus leniusculus Dana and its resistance to the parasitic fungus Aphanomyces astaci Schikora. Freshwater Crayfish, 5, 292298.

PETRUSEK A., FILIPOVÁ L., ĎURIŠ Z., HORKÁ I., KOZÁK P., POLICART., ŠTAMBERGOVÁ M., KUČERA Z., 2006. Distribution of the invasive spiny-cheek crayfish (Orconectes limosus) in the Czech Republic. Past and present. Bull. Fr. Pêche Piscic., 380-381, 903-918.

PÖCKL M., PEKNY R., 2002. Interaction between native and alien species of crayfish in Austria: Case studies. Bull. Fr. Pêche Piscic., 367, 763-776.

ŠTĚPÁN V.J., 1932-33. Soudobý stav rakařství v Čechách. [Current state of the crayfish fishery in Bohemia]. Separatum, ex: Československý rybář, 1932-33. Vodňany, 20 p. (in Czech).

UNESTAM T., 1969. Resistance to the crayfish plague in some American, Japanese and European crayfishes. Report of the Institute of the Freshwater Research Drottningholm, 49, 202-209.

VEY A., SÖDERHÄLL K., AJAXON R., 1983. Susceptibility of Orconectes limosus Raff. to the crayfish plague, Aphanomyces astaci Schikora. Freshwater Crayfish, 5, 284291.

VOLF F., 1926. Račí mor a hynutí raků v řece Volyňce. [The crayfish plague and the mortalities of crayfish in the river Volyňka.] Rybářský věstník, (7-9), 98-100, 116-118, 131-133 (in Czech).

VOTRUBEC J., 1931. Chov raků a velevruba perlonosného. [Culture of crayfish and the pearl mussel.] Textbook of the State school of fishery in Vodňany, vol. 9. Praha, $94 \mathrm{p}$. (in Czech). 
